\title{
PERAN KEMENTERIAN AGAMA KOTA MALANG DALAM MEMBINA KELUARGA MUALLAF
}

\author{
${ }^{1}$ Faridatus Syuhadak dan ${ }^{2}$ M. Farkhanudin \\ 1,2Universitas Islam Negeri Maulana Malik Ibrahim Malang \\ 1 farida.fh69@gmail.com \\ 2farkhan_tanjung@yahoo.co.id
}

\begin{abstract}
The purpose of this study is to find out how the condition of the family of muallaf under the guidance of the ministry of religion of the city of Malang, and to describe how the model of coaching the family convert by the ministry of religion of Malang. This research is empirical research. Which is processed qualitatively with case study approach. Primary data in this study was obtained from interviews with the family of muallaf in Malang. Secondary data was obtained from interviews with supervisors from the Ministry of Religious Affairs of Malang and reinforced with some literature. The data analysis is descriptive which describes keaadan family of muafaf and its pembinaanya model. The results of this study is, First background of the entry of Islam from every family of muallaf under the guidance of the Ministry of Religious Affairs of Malang is different. Many of them convert to Islam for following the religion of the husband and the calling of the heart. Finally, the mental and economic stress of the previous family is a necessity for the converts. This becomes a further problem in building a sakinah family. The families of converts are strong in aqidah, they can pray and pray. But not in balance with a good economy. Secondly, the model of muallaf coaching by the ministry of religion of the poor city has run well with the lecture model and the strengthening of aqidah, but its follow-up is related to building sakinah family and economic strengthening has not gone well.
\end{abstract}

Keyword: Coaching; Sakinah Family; Religion Convert

\section{Abstrak}

Tujuan penelitian ini adalah untuk mengetahui bagaimana kondisi keluarga muallaf dibawah binaan kementerian agama kota malang, dan untuk medeskripsikan bagaimana model pembinaan keluarga muallaf oleh kementerian agama kota malang. Penelitian ini adalah penelitian empiris. Yang diolah secara kualitatif dengan pendekatan studi kasus. Data primer dalam penelitian ini diperoleh dari wawancara dengan keluarga muallaf di Kota Malang. Data sekundernya diperoleh dari wawancara dengan pembina dari Kementerian Agama Kota Malang dan diperkuat dengan beberapa literatur. Analisis data bersifat deskriptif yang menggambarkan keaadan keluarga muallaf dan model pembinaanya. Hasil dari penelitian ini yaitu, Pertama latar belakang masuk islam dari setiap keluarga muallaf dibawah binaan Kementerian Agama Kota Malang itu berbeda beda. banyak dari mereka yang masuk Islam sebab mengikuti agama suami dan panggilan hati. Akhirnya tekanan mental, dan ekonomi dari keluarga sebelumnya adalah keniscayaan bagi para muallaf. Hal ini menjadi problem lanjutan dalam membangun keluarga sakinah. Para keluarga muallaf sudah kuat secara aqidah, mereka sudah bisa sholat dan mengaji. Namun tidak di imbangi dengan ekonomi yang baik. Kedua, model pembinaan muallaf oleh kementerian agama kota malang sudah berjalan dengan baik dengan model ceramah dan penguatan aqidah, namun follow up nya terkait membangun keluarga sakinah dan penguatan ekonomi belum berjalan dengan baik.

Kata kunci: Pembinaan; Keluarga Sakinah; Muallaf 


\section{PENDAHULUAN}

Dalam Islam orang yang baru masuk Islam disebut sebagai Muallaf. Muallaf di artikan sebagai seseorang yang dicondongkan hatinya pada Islam. Bagi sebagian Muallaf memutuskan untuk menjadi seorang Muallaf merupakan suatu hal yang tidak mudah, banyak dari mereka mengalami gejolak batin yang luar biasa. Karena mereka harus mempertimbangkan konsekuensi yang di terima seperti kehilangan pekerjaan, di kucilkan teman dan termasuk di benci keluarga. Namun, karena begitu berat cobaan seorang muallaf, Allah kemudian berfirman dalam surat $\mathrm{Al}$-Anfal ayat 38:

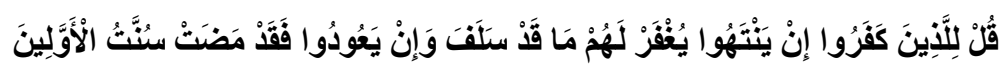

"Katakanlah kepada orang-orang yang kafir itu: "Jika mereka berhenti (dari kekafirannya), niscaya Allah akan mengampuni mereka tentang dosa-dosa mereka yang sudah lalu; dan jika mereka kembali lagi sesungguhnya akan berlaku (kepada mereka) sunnah (Allah tenhadap) orang-orang dahulu" (Al-Qur'an 8:38).

Dari ayat tersebut di jelaskan bahwa menjadi seorang Muallaf adalah sebuah keutamaan karena Allah akan mengampuni seluruh dosanya sebelum masuk Islam. maka setelah masuk Islam Muallaf menjadi seorang yang suci seperti bayi yang baru lahir.

Muallaf termasuk salah satu bagian dari masyarakat yang memerlukan bimbingan dan pembinaan, tujuan bimbingan tersebut adalah untuk meningkatkan kesadaran beragama, menanamkan keyakinan beragama, menghayati ajaran agama, melaksanakan ajaran agama tersebut dalam kehidupan sehari hari dan meningkatkan partisispasi dalam kegiatan kemasyarakatan serta pembangunan pada umumnya.

Malang adalah kota pendidikan, setiap tahun puluhan ribu mahasiswa baru ramai ramai datang untuk belajar di Malang. Malang juga di sebut sebagai kota wisata, setiap hari libur turis lokal maupun turis asing membanjiri setiap destinasi wisata di Malang. Bisa di bilang Malang adalah kota metropolitan. Dari sekian banyak orang yang datang ke Malang dengan latar belakang agama suku dan budaya yang berbeda Maka sangat memungkinkan terjadi adanya akulturasi agama dan budaya. termasuk perpindahan agama dari non Islam menjadi Islam atau di sebut dengan Muallaf.

Muallaf atau seseorang yang telah berikrar menyatakan dirinya memeluk Islam (melepaskan agama yang dulu), ia dituntut untuk melaksanakan kewajiban selaku seorang muslim dengan cara sedikit demi sedikit, dan tentu saja dalam hal pembinaan kearah itu terletak pada kaum muslimin selaku tuntutan fardhu kifayah.

Selama ini pembinaan keluarga Muallaf oleh Kementerian Agama secara formal dilakukan selama tiga kali dalam setahun di kantor Kementerian Agama, kemudian pembinaan secara non formal di lakukan oleh setiap penyuluh per kecamatan dengan cara mendatangi masing masing Muallaf. Muallaf yang terdata di Kementerian Agama Kota Malang berjumlah kurang lebih ada 70 Muallaf, namun dari data pembinaan terakhir tangal 16 februari 2017 Muallaf yang aktif 
mengikuti pembinaan secara formal hanya 21 Muallaf saja terdiri dari 11 Wanita dan 10 Pria. alasan para Muallaf memeluk agama Islam selain suka rela, juga karena adanya perkawinan, dan karena lingkungan sosial mereka yang sebagian besar beragama Islam.

Dalam kegiatan pemberdayaan atau pembinaan terhadap Muallaf atau keluarga Muallaf menjadi suatu hal yang tidak kalah penting. Karena sebagai orang yang menjalani keyakinan baru haruslah memahami prinsip-prinsip ajarannya, karena merupakan pedoman hidup yang harus diterapkan dalam kehidupan sehari-hari. Suatu hal yang mustahil apabila seseorang dapat memetik manfaat dari suatu ajaran sedangkan tidak mempelajari dan memahami ajaran tersebut (Prawira, 2001).

Bagi muallaf laki laki mempunyai problem yang lebih berat dari pada perempuan, sebab disamping dia harus memperkuat agama yang dia peluk juga harus memperkuat keluarga sakinah sesuai dengan nilai islam. Oleh karena itu, jika tidak di bina dan di landasi dengan nilai dasar agama dalam menjalin hubungan keluarga maka bukan sesuatu yang mustahil akan terjadi perceraian. Pembinaan keluarga sakinah belum maksimal dilaksanakan dalam artian pelaksanaannya tidak terprogram secara jelas dan belum berjalan dengan maksimal. Dengan demikian, para tokoh agama memegang peranan yang sangat penting, agar pembinaan keluarga Muallaf dapat terlaksana dengan baik.

Pembinaan Muallaf secara khusus adalah tanggung jawab Kementerian Agama. Namun secara umum adalah tanggung jawab semua umat, seperti ustad, kiai, dan orang Islam yang paham agama Islam. Baik itu membina secara formal maupun non formal.

Tabel 1. Penelitian Terdahulu

\begin{tabular}{|c|c|c|c|c|}
\hline No & Penulis & Judul & Persamaan & Perbedaan \\
\hline 1 & $\begin{array}{lr}\text { Afifatur } & \text { Rohma } \\
\text { Fakultas } & \text { Syari'ah } \\
\text { Jurusan Al Ahwal Al } \\
\text { Syakhsiyah } 2011 .\end{array}$ & $\begin{array}{lr}\text { Penguatan } & \text { Keluarga } \\
\text { Sakinah } & \text { Pada } \\
\text { Franchisor } & \text { Dan } \\
\text { Franchisee } & \text { Little } \\
\text { Camel, Printingku, } & \text { Pan } \\
\text { Doetoekoe } \\
\text { Melalui } & \text { Bisnis } \\
\text { Franchisee. }\end{array}$ & $\begin{array}{l}\text { Model } \\
\text { pembinaan } \\
\text { keluarga } \\
\text { sakinah }\end{array}$ & $\begin{array}{l}\text { Penelitian kepada } \\
\text { Muallaf di lingkugan } \\
\text { kecamatan Klojen. }\end{array}$ \\
\hline 2 & \begin{tabular}{lr} 
Alaika & Kurnia \\
Adzim, & Fakultas \\
Dakwah & Dan \\
Komunikasi & UIN \\
Walisongo & \\
\multicolumn{2}{l}{ Semarang } \\
2015.
\end{tabular} & $\begin{array}{l}\text { Pembinaan } \\
\text { Keluarga Sakinah } \\
\text { Perspektif Dakwah } \\
\text { (Studi Kasus Di Kua } \\
\text { Ngaliyan). }\end{array}$ & $\begin{array}{l}\text { Pembinaan } \\
\text { keluarga } \\
\text { sakinah }\end{array}$ & $\begin{array}{l}\text { Obyek yang di bina } \\
\text { dalam penelitian ini } \\
\text { adalah keluarga } \text { Muallaf. }\end{array}$ \\
\hline 3 & $\begin{array}{lr}\text { Washilatur } & \text { Rahmi } \\
\text { Fakultas Dakwah } \\
\text { Dan Komunikasi } \\
\text { UIN Syarif Jakarta } \\
\text { 2008. }\end{array}$ & $\begin{array}{lr}\text { Bentuk } & \text { Komunikasi } \\
\text { Pembinaan } & \text { Muallaf } \\
\text { Daarut } & \text { Tauhid } \\
\text { Jakarta } & \end{array}$ & $\begin{array}{l}\text { Tentang } \\
\text { pembinaan } \\
\text { Muallaf }\end{array}$ & $\begin{array}{l}\text { Pada penelitian kali ini } \\
\text { obyeknya adalah } \\
\text { keluarga Muallaf }\end{array}$ \\
\hline 4 & Apriyanto Program & Pelaksanaan & Tentang & Pada penelitian di BMC \\
\hline
\end{tabular}




\begin{tabular}{|c|c|c|c|c|}
\hline & $\begin{array}{lr}\text { Studi } & \text { Pendidikan } \\
\text { Agama } & \text { Islam } \\
\text { Fakultas } & \text { Tarbiyah } \\
\text { Dan Ilmu Keguruan } \\
\text { Institut } & \text { Agama } \\
\text { Islam Negeri (Iain) } \\
\text { Purwokerto 2016. }\end{array}$ & 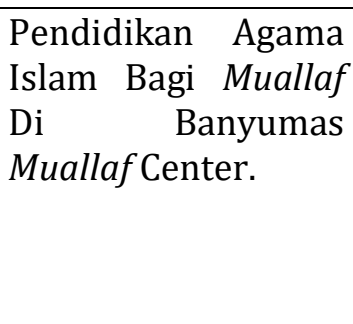 & $\begin{array}{l}\text { pembinaan } \\
\text { pengembangan } \\
\text { Muallaf. }\end{array}$ & $\begin{array}{l}\text { obyeknya } \\
\text { Muallaf secara umum, } \\
\text { bukan keluarga Muallaf. }\end{array}$ \\
\hline 5 & $\begin{array}{l}\text { Nur Fadillah, } \\
\text { Universitas } \\
\text { Padjadjaran } \\
\text { Fakultas Ilmu } \\
\text { Komunikasi Jurusan } \\
\text { Manajemen } \\
\text { Komunikasi } 2013 .\end{array}$ & \begin{tabular}{lr}
\multicolumn{2}{l}{ Komunikasi } \\
Persuasif & Pengurus \\
Masjid & Dalam \\
Pembinaan & Muallaf \\
Etnis Cina & Melalui \\
Kegiatan & Dakwah \\
(Study Kasus Di \\
Masjid Lautze 2 \\
Bandung).
\end{tabular} & $\begin{array}{l}\text { Mempunyai } \\
\text { kesamaan } \\
\text { bertujuan } \\
\text { untuk } \\
\text { mengetahui } \\
\text { konsep dakwah } \\
\text { pembinaan } \\
\text { Muallaf. }\end{array}$ & $\begin{array}{lr}\text { Dalam penelitian ini } \\
\text { obyeknya } & \text { hanya } \\
\text { Muallaf, } & \text { sedangkan } \\
\text { penulis } & \text { tentang } \\
\text { keluarga } & \text { Muallaf. }\end{array}$ \\
\hline
\end{tabular}

Sedangkan tujuan dari penelitian adalah pertama mengetahui bagaimana kondisi religiusitas keluarga mullaf dibawah binaan kementerian agama kota malang, kedua bagaimana model pembinaan keluarga muallaf oleh kementerian agama kota malang.

\section{METODE PENELITIAN}

Penelitian ini berjenis penelitian hukum sosiologis empiris. Karena dalam penelitian ini, penulis mendeskripsikan secara detail dan mendalam tentang realitas pembinaan keluarga yang dilakukan oleh Kementerian Agama Kota Malang (Amiruddin \& Asikin, 2004).

Pendekatan yang digunakan dalam penelitian ini adalah pendekatan case study karena peneliti melakukan penelitian terkait pembinaan muallaf di Kementerian Agama Kota Malang (Bogdan \& Biklen, 1992). Kemudian data tersebut diolah secara kualitatif. Artinya, informasi berupa kata-kata (jawaban) informan menjadi data utama dalam penelitian ini. Data tersebut kemudian digambarkan secara sistematis, faktual, dan akurat. sehingga diperoleh interpretasi yang dapat menjawab tujuan penelitian dengan tepat.

Sumber data primer pada penelitian ini adalah para keluarga Muallaf yang berada di bawah naungan Kementerian Agama kota Malang. Pada penelitian kali ini ada lima keluarga Muallaf, terdiri dari ibu sri, ibu eny, ibu sofia, ibu agip dan ibu lusy. dari data yang peneliti dapatkan dari absensi pada saat pembinaan sebenarnya ada 21 keluarga Muallaf, semua sudah beberapa kali peneliti menghubungi baik melalui telfon atau sms atau wa namun yang membalas hanya 6 keluarga Muallaf saja. tetapi kebetulan 6 orang ini adalah stakeholdernya atau koordinator dari para keluarga Muallaf yang di bina oleh Kementerian Agama kota Malang.

Sumber data sekunder adalah para Pembina Muallaf yaitu bu mahmudah, penyuluh di KUA klojen, Pak Basuki selaku penanggung jawab penyelenggara pembinaan Muallaf di Kementerian Agama. Kemudian dilengkapi dengan buku buku seperti tafsir al misbah karya 
qurais shihab. Dan buku pedoman pembinaan muallaf dari kementerian agama karya sudirman kamil.

Teknik pengumpulan data pada penelitian kali ini adalah dengan menggunakan wawancara terstruktur (structured interview), yaitu peneliti menyiapkan dulu pertanyaan terkait pembinaan keluarga muallaf. Metode lain adalah dokumentasi, peneliti merekam pada saat wawancara dengan muallaf dan memfoto data data pada waktu observasi.

Dari data yang diperoleh tersebut kemudian di edit atau di periksa ulang, dengan tujuan data tersebut berkualitas baik (LKP2M, 2005). Kemudian classifying (pengelompokan), dimana data hasil wawancara diklasifikasikan berdasarkan kategori dari muallaf, berdasarkan pertanyaan dalam rumusan masalah. Setelah diklasifikasikan, data menjalani proses verifying, agar data yang dihasilkan diketahui dengan jelas sumbernya. Proses selanjutnya adalah analysing (analisa). Analysing meliputi penyederhanaan data ke dalam bentuk yang lebih mudah dibaca dan diinterpretasikan (Singarimbun \& Effendi, 1987). Langkah terakhir adalah concluding (penarikan kesimpulan).

\section{HASIL DAN PEMBAHASAN}

Penjelasan tentang kondisi keluarga muallaf dibawah binaan Kementerian Agama Kota Malang

Kementerian Agama Kota Malang selama ini menjadi central pembinaan bagi muallaf di Kota Malang, dalam 2 tahun terakhir yaitu tahun 2016 dan 2017. data yang ada di Kementerian Agama Kota Malang menunjukan kurang lebih ada 70 muallaf di Kota Malang. Hampir seluruh dari muallaf sudah berkeluarga. namun dari setiap pasutri hanya salah satu yang muallaf, jika tidak suami maka istrinya yang muallaf. Latar belakang setiap muallaf yang masuk Islam sangat beragam, ada yang karena pernikahan ada pula yang karena bertanya tanya tentang konsep ketuhanan dan ada yang lewat mimpi.

Latar belakang ekonomi dari setiap keluarga muallaf di Kota Malang juga sangat beragam, namun mayoritas dari mereka bekerja sebagai pegawai swasta atau buruh, ada juga yang bekerja sebagai pembantu rumah tangga bahkan ada juga yang buruh cuci atau setrika. Sedangkan suminya bekerja sebagai tukang, buruh dan pegawai swasta. Hal ini jauh dari kemapanan. Seorang muallaf tidak hanya mengalami transformasi iman, tapi seluruh aspek hidupnya. Bisa di katakan memulai kehidupan baru dari nol. Karena dari mereka ada yang dilepas keluarganya dan akhirnya tidak ada keluarga, ada yang dikucilkan temanya ada yang dipecat dari pekerjaan lamanya.

Fenomena seperti ini bukanlah hal yang mudah untuk dialami, jika tidak kuat menghadapinya bukan hal yang mustahil jika muallaf kembali kepada agama sebelumnya. oleh karena itu harus ada organ atau lembaga yang membina muallaf untuk menjadi teman bahkan 
keluarga baru bagi muallaf. Kondisi kelurga dari masing masing muallaf yang satu sama lain sibuk dalam hal mencari uang menjadi kendala pokok dalam mempelajari agama. Oleh sebab itu banyak dari mereka yang belum bisa mengaji, dan belum dalam dalam mempelajari agama Islam. Dari gambaran secara umum diatas berikut para keluarga muallaf yang penulis sudah wawancara.

Yang pertama adalah Bu Eny seorang pembantu rumah tangga berumur 39 tahun, beliau masuk Islam sejak menikah. suaminya sales roti, anaknya dua. Beliau muallaf dari Surabaya, Pada wawancara tersebut di jelaskan bahwa ketika Bu Eny mau masuk Islam ketika mau menikah dengan suaminya. tantangan terberat malah datang dari keluarga bahkan ibunya sendiri. Namun Bu Eny tetep ngotot masuk Islam. kondisi seperti ini merupakan pilihan berat bagi Bu Eny tapi karena keyakinan atau hidayah Bu Eny memutuskan pilihanya untuk masuk Islam. setelah masuk Islam Bu Eny belum melaksanakan rukun Islam sepenuhnya, tapi berjalanya waktu Bu Eny mau sholat dan belajar agama secara mendalam dengan ustad setempat.

Kondisi ekonomi Bu Eny dan keluarganya sangat mengkhawatirkan. Jika imanya tidak kuat maka cepat atau lambat Bu Eny akan kembali ke agama semula. Karena disamping Bu Eny dilepas keluarganya, beliau juga di hadapkan dengan kondisi ekonomi yang sulit. Padahal sebenarnya peluang Bu Eny untuk hidup enak terbuka lebar jika beliau masuk Kristen lagi. Jika Bu Eny kembali lagi kepada agama sebelumya ini bukan salah Bu Eny namun salah masyarakat Islam sekitarnya karena tidak mau membantunya. Kondisi keluarga beliau juga harmonis, karena saling mengerti. Walaupun Bu Eny keras, suami Bu Eny merupakan suami yang penyabar.

Selanjutnya adalah Bu Sri, muallaf dari pulau Bali, sekarang tinggal di mergosono gang III, umur 43 tahun, agama sebelumnya hindu. Bu Sri bekerja sebagai buruh cuci setrika dipondoknya Alm K.H Masduki mergoso, suaminya kuli bangunan. Sebelum ke Malang Bu Sri sudah menikah dan memiliki satu orang anak, namun Bu Sri mengalami gejolak hati. Dan memutuskan pindah ke Malang dan bercerai dengan suami sebelumnya. Bu Sri akhirnya pindah ke Malang dan ngabdi di Pondok Alm K.H. Masduki mergosono, sampai akhirnya Bu Sri bertemu dengan seorang laki laki yang sekarang menjadi suaminya. Dari paparan beliau dijelaskan bahwa Bu Sri masuk Islam sejak beliau datang ke Malang, dan mengabdi di pondok alm K.H. Masduki mergosono, Bu Sri memulai kehidupan baru di Malang, sampai akhirnya Bu Sri bertemu dengan seorang laki laki yang sekarang menjadi suaminya. Kondisi saat itu merupakan kondisi yang sulit bagi Bu Sri karena harus meninggalkan suami, anak, keluarganya demi agama yang baru dipilihnya. Namun dengan keyakinan iman Bu Sri, Bu Sri sabar menjalani kehidupan yang barunya. 
kondisi keluarga Bu Sri baik baik saja, bahkan prestasi anak anaknya sangat bagus Karena ketiganya dapat beasiswa, namun hal itu tidak di dukung kondisi ekonomi Bu Sri yang mapan, malah sekarang Bu Sri di lilit hutang oleh rentenir. Secara pengetahuan Islam Bu Sri juga sudah banyak mengerti malah suaminya yang Islam dari kecil Bu Sri ajarin ngaji bahkan kadang tidak sholat.

Selanjutnya bu sofia bekerja sebagai penjahit, suaminya bekerja di pemerintah daerah. Asli Malang Alamat blimbing Umur 48 tahun, Bu Sofia masuk agama Islam sejak SMA, agama sebelumnya Kristen alasan Bu Sofia masuk Islam karena pada saat itu Bu Sofia muncul keingintahuan tentang yesus akhirnya beliau masuk Islam karena jawaban pasteurnya tidak memuaskan. Bu Sofia masuk Islam karena ketidakpuasan dengan agama sebelumnya, beliau masuk Islam sejak masuk SMA Islam. padahal saat itu beliau dilarang bapaknya. Bu Sofia setelah menikah baru mendalami agama Islam secara lebih dalam dengan ustad setempat. Namun sekarang belum bisa membaca alquran. Suaminya juga yang Islam sejak kecil malah nggak bisa membaca alquran juga.

Kondisi rumah tangga Bu Sofia harmonis saling mengerti, di dukung ekonomi yang cukup. Suami Bu Sofia juga gampangan nggak mudah marah, Namun kadang bikin kesal Bu Sofia karena nggak sempat mengajari anaknya mengaji, sholat dan lain lain.

Selanjutnya bu lusy agama sebelumnya Kristen, Bu Lusy bekerja sebagai buruh di sebuah pabrik di Bandulan, suami saya bekerja sebagai buruh juga, anaknya 1, kondisi keluarga tergolong masih muda karena Bu Lusy masih berumur 25 dan suaminya 26.

$\mathrm{Bu}$ Lusy sebenarnya sudah lama masuk agama Islam, sejak beliau masih kecil. Namun Bu Lusy belum serius karena masih ikut ikut mamanya, namun setelah Bu Lusy mau menikah, $\mathrm{Bu}$ Lusy meniatkan dirinya dengan sungguh sungguh untuk masuk Islam. akhirnya Bu Lusy belajar dengan ustad di desanya dan dengan suami. Sekarang sudah bisa sholat lima waktu dan masih belajar mengaji.

$\mathrm{Bu}$ Lusy dan suaminya sangat santai dalam menanggapi masalah keluarga yang di hadapinya, beliau menganggap wajar jika keluarga pasti ada masalah, tinggal saling mengerti aja, jangan berlebihan dalam menanggapi masalah, dari segi ekonomi walaupun Bu Lusy dan suaminya hanya sebagai buruh pabrik, Bu Lusy merasa cukup dengan rezeki yang tuhan berikan.

Selanjutnya Bu Agip Agama sebelumnya kristen, alamat di perumahan sukun pondok indah blok cc no 04, jalan klayatan III sukun. Umurnya 35 tahun, saya bekerja di salon dee suhad. Suami muslim sejak lahir bekerja di pabrik sebagai operator flipper umurnya 34 tahun. anak satu. Bu Agip masuk Islam sejak menikah, namun sebenarnya Bu Agip sejak kecil ingin masuk Islam namun takut dengan kakeknya, karena kakeknya di besarkan sama orang Kristen, 
akhirnya setelah kakek Bu Agib meninggal Bu Agib berani masuk Islam lalu menikah dengan seorang laki laki yang sekarang menjadi suaminya.

Bagi Bu Agip walaupun beliau masih baru paham agama namun sebisa mungkin untuk meminimalisir pertengkaran dengan saling menghargai dan mengerti, walaupun Bu Agip dan suaminya sama sama keras. Bu Agip belum bisa mengaji, sholat pun bisanya cuman sholat lima waktu, yang lainya belum bisa. Hal ini di karenakan Bu Agip dan suaminya sama sama sibuk.

Setiap seorang muallaf dalam perjalananya masuk Islam sangat variatif, motivasi mereka dalam memeluk agama Islam juga sangat variatif, termasuk kondisi ekonomi keluarga dan sosialnya. Namun mereka menginkan keluarga menjadi keluarga yang sakinah. Yaitu adanya kasih sayang dalam keluarga, harmonis dan terpenuhi aspek insfrastruktur (sandang pangan papan), Sedangkan Seperti yang di ungkapkan Bu Eny di atas dari segi ekonomi sangat minim bahkan jauh dari kata mapan. Rumah saja masih mengontrak, akhirnya $\mathrm{Bu}$ Eny harus memikirkan setiap tahun biaya untuk mengontrak. Bu Eny juga bingung tentang pendidikan anaknya nanti padahal sebentar lagi masuk smp, pasti membutuhkan biaya yang banyak. sedangkan Bu Eny sekarang hanya bekerja sebagai pembantu. Sebagai pembantu penghasilan Bu Eny hanya cukup untuk memenuhi kebutuhan sehari hari. Suaminya bekerja sebagai sales roti, gajinya ju tidak terlalu besar, Bu Eny juga sering kali di tawari pekerjaan yang enak jika Bu Eny mau masuk Islam. diaspek lain secara agama Bu Eny sudah kuat hal itu diketahui dar Bu Eny mewajibkan suami dan anaknya untuk sholat berjamaah. Bu Eny walaupun muallaf beliau sangat keras soal ibadah, anaknya jika tidak sholat maka Bu Eny pukul, demikian juga suaminya pasti di marah marahi jika tidak sholat. Bu Eny sudah sholat lima waktu dan tak pernah bolong, sudah bisa puasa full dan sudah bisa mengaji. hubungan rumah tangganya juga harmonis. $\mathrm{Bu}$ Eny sosok yang keras namun diimbangi suami yang penyabar. Yang sangat mengerti sifat Bu Eny. akhirnya tercipta hubungan yang harmonis. Dalam Islam muallaf di kenal dengan orang yang di bujuk hatinya. Ulama bahkan menganjurkan agar muallaf di berikan bantuan secara moril maupun materiil karena supaya muallaf merasa di perdulikan dan semakin kuat imanya. Karena jika muallaf yang dengan kondisi ekonomi sulit kemudian tidak diberikan bantuan di takutkan akan masuk kembali ke agama sebelumnya.

Tidak jauh beda dengan Bu Eny, Bu Sri juga memiliki masalah dalam ekonomi. Bu Sri yang hanya bekerja sebagai buruh strika kini belum punya rumah permanen, sampai saat ini Bu Sri hanya mengontrak rumah dimergosono, suaminya hanya sebagai kuli bangunan. Jauh sekali dari kata mapan, beruntung Bu Sri di karuniai anak yang pintar dan manutan, ketiga anak Bu Sri mendapat beasiswa dari sekolahnya Karena prestasi yang di dapat. Bu Sri yang sebagai muallaf belum terpenuhi agama oleh suaminya, karena suaminya malah kadang tidak sholat. Namun $\mathrm{Bu}$ Sri tidak pernah menganggap itu sebagai masalah, Bu Sri memahami pekerjaan suaminya yang berat. Bahkan Bu Sri menutupi hutang yang Bu Sri pinjam di rentenir dari suaminya, Bu Sri tak 
mau suaminya tau, karena tak mau membebani suaminya. Akhirnya Bu Sri membayar bunga hutang tersebut dengan gajinya setiap bulan.

Berbeda dengan kondisi Bu Sofia, Bu Sofia secara ekonomi sudah cukup mapan, rumah Bu Sofia sudah milik sendiri. Suami bekerja di pemda, gajinya sudah cukup untuk memenuhi kebutuhan sehari hari. Bu Sofia membantu ekonomi keluarga dengan bekerja sebagai seorang penjahit. Namun Bu Sofia belum bisa mengaji akhirnya anaknya Bu Sofia pun tidak bisa ikut mengaji padahal sudah SMA, suami Bu Sofia kurang begitu aktif dalam mengajarka agama pada keluarganya. Bu Sofia sebenarnya butuh guru ngaji untuk mengajari anaknya sholat dan mengaji. beliau ingin sekali anaknya bisa mengaji, supaya bisa menjadi bekal nanti di akhirat. $\mathrm{Bu}$ Sofia dengan suaminya cukup harmonis, ditandai dengan jarang bertengkar dengan suaminya cuman kadang kesal saja karena suaminya tidak mau mengajari anaknya agama.

Tidak jauh berbeda dengan Bu Eny dan Bu Sri, Bu Lusy juga terdapat masalah di ekonomi, Bu Lusy sekarang belum memiliki rumah yang permanen, Bu Lusy sekarang numpang di rumah orangtuanya, Bu Lusy dan suaminya bekerja sebagai buruh pabrik di bandulan. Rumah tangganya masih sangat muda, Bu Lusy belum punya anak, namun usia pernikahan yang muda tidak menjadikan rumah tangga yang labil, yang sering bertengkar dan cekcok. Usia pernikahan Bu Lusy yang masih seumur jagung malah menjadikan Bu Lusy dan suaminya saling mengerti dan menjaga satu sama lain. Namun dengan kondisi Bu Lusy yang sibuk kerja karena berbeda sip, suami Bu Lusy tidak sempat mengajari agama Islam, Bu Lusy belajar agama Islam dengan ikut pengajian dan belakar kepada ustad setempat.

Tidak jauh beda dengan Bu Sofia, Bu Agip sebagai seorang muallaf beliau tidak memiliki masalah ekonomi. Rumah Bu Agip sudah milik sendiri, Bu Agip bekerja di salon, hal itu menjadikan suami akhirnya menjadi pencemburu. Namun itu bukan menjadi suatu masalah, karena Bu Agip selalu tidak tega jika suaminya marah terus diam dan diikuti mogok makan. Akhirnya setelah tak tega Bu Agip menghampiri suaminya yang mogok makan dan mengajak baikan, suasana seperti ini malah menjadi harmonis ketika mereka saling mengerti. Suami Bu Agip bekerja di pabrik, akhirnya karena sama sama sibuk, Bu Agib tidak bisa belajar agama dengan suaminya. Sampai saat ini Bu Agip belum bisa mengaji, sholatpun hanya lima waktu, Bu Agip belajar agama dengan tetangganya.

Berdasarkan analisis di atas dapat diketahui bahwa setiap keluarga muallaf memiliki kondisi yang berbeda beda baik segi ekonomi, agama, sosial maupun kebutuhan dari setiap keluarga muallaf. Perbedaan ini dipengaruhi karena latar belakang mereka berbeda beda, motivasi mereka masuk Islam juga berbeda. kondisi lingkungan juga berbeda. Namun sejauh ini kondisi keluarga muallaf di kota Malang masih harmonis, hal ini di gambarkan dengan terciptanya rasa saling mengerti dan saling memahami walaupun dengan kondisi pengetahuan agama yang minim. Hanya saja tidak semua keluarga muallaf memiliki kondisi ekonomi yang 
baik, dan perkembangan pengetahuan Islam yang baik. Hal ini di gambarkan dari bebrapa keluarga muallaf yang belum bisa mengaji, dan sholat dengan baik walaupun sudah bertahun tahun memeluk agama Islam.

Berikut merupakan tabel yang menggambarkan bagaimana kondisi keluarga muallaf di Kota Malang, sudahkah termasuk didalam keluarga indicator keluarga sakinah.

Tabel 2. Kondisi keluarga muallaf di lingkungan Kementerian Agama Kota Malang

\begin{tabular}{|l|l|l|l|}
\hline No & Keluarga & Kategori sakinah & Indicator (sandang pangan papan) \\
\hline 1 & Bu Eny & Pra sakinah & $\begin{array}{l}\text { Agama sudah kuat, keluarga harmonis tapi Tidak } \\
\text { memiliki tempat tinggal tetap. }\end{array}$ \\
\hline 2 & $\mathrm{Bu}$ Sri & Pra sakinah & $\begin{array}{l}\text { Pendidikan anak sudah bagus, sudah harmonis } \\
\text { tapi Tidak memiliki tempat tinggal tetap. }\end{array}$ \\
\hline 3 & $\mathrm{Bu}$ Sofia & Sakinah I & $\begin{array}{l}\text { Pendidikan anak sudah terpenuhi, rumah sudah } \\
\text { hak milik, sudah bisa baca alquran. }\end{array}$ \\
\hline 4 & Bu Lusy & Pra sakinah & $\begin{array}{l}\text { Tidak memiliki tempat tinggal yang tetap. Belum } \\
\text { bisa mengaji. }\end{array}$ \\
\hline 5 & Bu Agip & Pra sakinah & $\begin{array}{l}\text { Agama sudah kuat namun belum bisa mengaji, } \\
\text { rumah sudah hak milik. }\end{array}$ \\
\hline
\end{tabular}

Dari kategori keluarga muallaf di atas, yang masuk dalam kategori keluarga sakinah III tidak ada, keluarga sakinah II tidak ada, keluarga sakinah I satu keluarga, dan pra sakinah 4 keluarga muallaf. Dari hasil tersebut menunjukan bahwa para keluarga muallaf mayoritas belum terkategorikan sebagai keluarga sakinah Karena belum memahami pengetahuan agama dengan baik, seperti bisa mengaji, sholat dengan baik. memang secara aqidah sudah yakin, Namun jika secara aqidah mereka sudah yakin maka harus di kembangkan pengetahuanya terkait bagaimana cara berIslam dengan baik. Cara menjalankan agama Islam dengan baik. Kemudian terkait indikator lain seperti terjalinya rasa kasih sayang di dalam keluarga muallaf, mayoritas keluarga muallaf sudah saling mengasihi dibuktikan dengan jarang bertengkar dan mengerti satu sama lain. Namun terkait terpenuhinya aspek insfrastruktur (sandang pangan papan) para muallaf masih banyak yang lemah secara ekonomi, sehingga rentan akan adanya bujukan dari agama lain. Ini merupakan tanggung jawab orang Islam lainya yang lebih dulu dan tau akan agama Islam. seperti kiai, ustad dan orang orang terdekat yang paham akan agama Islam. untuk mengajarkan bagaimana mengaji, bagaimana sholat dengan baik dan berIslam dengan baik serta memperkuat ekonomi.

Sebab keluarga mullaf ada yang tidak bisa mengaji dan sholat serta lemah dalam ekonomi adalah karena sebagian suami mereka yang Islam sejak lahir tidak maximal dalam membina istri, karena sibuk bekerja, dan ada juga yang sama sama sibuk bekerja, akhirnya secara internal keluarga muallaf tidak ada yang bimbing, kemudian jika lemah dari segi ekonomi itu 
dikarenakan muallaf sudah tidak memasuki usia produktif seperti Bu Sri. Jadi walaupun diberikan modal maka akan sulit untuk berkembang. Sedangkan muallaf yang masih muda dikarenakan kurangnya skill yang dimiliki, akhirnya mereka bekerja sebisa mereka, seperti menjadi buruh dan pembantu. Dari zaman nabi Muhammad sampai sekarang pendapat ulama maupun sahabat tentang bagaimana Islam memperlakukan muallaf sudah mengalami beberapa transformasi, ada yang mengatakan bahwa muallaf yang di bujuk hatinya zaman sekarang sudah tidak ada, ada yang mengatakan ada pada setiap zaman, jika ditarik ke zaman sekarang realita muallaf yang dibujuk hatinya masih ada dengan bukti tersebut, cara Islam memperlakukan muallafpun juga harus mengalami trasnformasi atau perubahan yang tetap mempertahankan cara lama yang baik dan menggunakan cara baru yang baik sesuai dengan realitas zaman sekarang. Apa lagi zaman sekarang banyak aliran radikalisme yang sangat cepat menyebar dimasyarakat, bisa jadi jika para muallaf tidak di bimbing dan di perhatikan dengan baik maka akan menjadi sasaran empuk bagi para penyebar paham Islam garis keras yang justru akan berbahaya bagi Islam sendiri karena akan malah merusak citra Islam.

Secara umum terkait kondisi keluarga dari lima keluarga muallaf sudah menunjukan signifikansi yang bagus kaitanya dengan pengetahuan agama, aqidah dan keluarga sakinah. hanya saja masih butuh pengembangan pengetahuan akan agama Islam, penguatan ekonomi dan hal hal pokok seperti sholat dan mengaji. oleh karena itu peran dari orang Islam lainya sangat penting terutama Kementerian Agama Kota Malang dalam mengupayakan keluarga muallaf agar menjadi keluarga sakinah yang kaffah.

\section{Pembinaan keluarga muallaf oleh Kementerian Agama Kota Malang}

Muallaf sebagai orang yang baru masuk Islam seperti seorang bayi yang baru lahir, mereka harus belajar merangkak dalam mengetahui apa itu agama yang baru dipilihnya, kemudian berjalan untuk menjalankan apa yang telah di wajibkan kepadanya. Oleh karena itu muallaf di katakan orang yang lemah dalam hal agama, muallaf masih sangat butuh bimbingan dalam menjalankan sholat, puasa termasuk membina keluarga sakinah bagi yang sudah berkeluarga, agar mereka menjadi muslim yang baik dan tidak kembali lagi ke agama sebelumnya. Berikut data para informan terkait pembinaan muallaf di Kota Malang:

Pertama adalah Bu mahmudah, beliau adalah penyuluh di KUA Klojen Kota Malang, beliau membuka suara terkait pembinaan yang dilakukan oleh Kementerian Agama Kota Malang. Bu Mahmudah beranggapan bahwa pembinaan selama ini dilakukan selama 3 bulan sekali, penyelenggaranya adalah Kementerian Agama, MUI, penyuluh KUA sekota Malang dan baznas, pembinaan dilaksanakan di hari minggu jam 8-12 siang dengan pemateri K.H. Baidlowi muslih dari MUI kota Malang modelnya ceramah dan tanya jawab. Bu mahmudah juga mengatakan bahwa selama ini pembinaan sudah berjalan maksimal jika dilaksanakan pada hari libur, dan 
kurang maksimal bila dilaksanakan dihari efektif. terkait pembinaan yang door to door atau personal perindividu, terdapat kendala yakni waktu, penyuluh hanya bisa membina secara personal hanya pada jam kerja, sedangkan para muallaf bisa dibina jika diluar jam kerja seperti malam atau weekend.

Selanjutnya adalah Pak Tri Basuki, selaku kasi penyelengara syariah di Kementerian Agama Kota Malang, beliau sebagai penangung jawab dari pembinaan muallaf di Kota Malang. Beliau membuka suara terkait pembinaan yang selama ini di lakukan.

Pak Basuki menjelaskan bahwa muallaf itu ada dua kategori, yang konsumtif dan produktif, jika yang konsumtif maka di kasih alquran dan uang. Sedangkan jika yang produktif maka dikasih uang tambahan modal dengan cara kerja sama dengan baznas. Pak Basuki juga menuturkan bahwa pembinaan muallaf itu tersentral di Kementerian Agama, pembinaan dilakukan di hari minggu dari jam 8-12 modelnya ceramah dan Tanya jawab, selama ini sudah empat kali namun hanya sebatas penguatan iman, ekonomi dan sosial. Sedangkan itu semua sudah temasuk dalam indicator pendukung keluarga sakinah. jadi walaupun di Kementerian Agama itu tidak ada pembinaan khusus terkait keluarga sakinah, namun indicator pendukung terkait keluarga sakinah sudah di masukan ke dalam pembinaan. Pak Basuki juga mengatakan bahwa pembinaan keluarga muallaf tidak dilaksanakan disetiap KUA karena keterbatasan sumber daya dan terbatas muallaf. Akhirnya pembinaan yang dilakukan di setiap KUA atau kecamatan yaitu dengan pembinaan non formal, yakni penyuluh datang ke rumah muallaf untuk memberikan follow up materi dan juga sebagai mediator sekaligus tempat curhat bagi muallaf terkait masalah apapun yang sedang dihadapinya. Selama ini penyuluh di setiap KUA atau kecamatan yang PNS berjumlah 7 yang non PNS berjumlah 41, mereka sevagai ujung tombak dalam hal pembinaan karena yang bersentuhan langsung dengan muallaf yang tau masalahnya muallaf. Pak Basuki kemudian menjelaskan terkait tolak ukur pembinaan itu dikatakan maksimal atau tidak, kata pak Basuki semua itu di kembalikan kepada muallaf pak Basuki hanya upaya saja. Jika muallafnya memang rajin membaca buku rajin ikut pengajian di desa dan aktif mempelajari agama maka itu sudah dikatakan maksimal, namun sebaliknya jika muallafnya aras arasen atau malas, maka akan jauh dari kata maksimal. Pak Basuki juga menjelaskan terkait pembinaan dari segi ekonomi, muallaf ditawari pinjaman modal untuk yang sudah berusaha, untuk yang belum maka muallaf dibina terkait pengembangan skill supaya lebih produktif. Pak Basuki juga berpendapat bahwa sebenarnya masjid yang sudah surplus atau sudah banyak uangnya maka bisa menjadi solusi bagi ekonomi muallaf.

Selanjutnya Gus Sulton, beliau adalah penanggung jawab ZIS di Baznas Kota Malang, beliau menjelaskan terkait procedural muallaf mengajukan modal pinjaman ke Baznas. Pak sulton menjelaskan bagi muallaf yang ingin mengajukan pinjaman modal ke baznas model pengajuanya adalah kelompok, syaratya hanya jujur. Beliau juga mengatakan bahwa tujuan 
dijadikan kelompok bukan untuk mempersulit namun untuk mempermudah Baznas dalam menagih angsuran ke muallaf. Namun Baznas juga selektif dalam memberikan pinjaman modal. Maksudnya adalah hanya bagi yang usahanya sudah jalan, bagi yang belum jalan atau yang masih mau mulai, baznas tidak berani memberikan pinjaman. Namun baznas memberi solusi dengan mengajari skill berusah, setelah itu juga sudah mahir maka baru dikasih uang pinjaman modal.

Kemudian keluarga muallaf dibawah binaan naungan Kementerian Agama Kota Malang yang dapat peneliti wawancara:

Bu Eny menjelaskan tentang pembinaan yang selama ini dilakukan oleh Kementerian Agama Kota Malang. Bu Eny menjelaskan bahwa pembinaan yang dilakuakan selama ini baru 4 kali, salah satunya buka bersama. Isinya hanya ceramah ceramah tentang penguatan aqidah, pembinaan dilaksanakan setiap hari minggu jam 8-12 siang. Setelah itu pulang dan dikasih uang seratus ribu. Awal pembinaan di kasih buku agama dan alquran. Menurut Bu Eny pembinaan kurang efektif karena hanya ceramah saja, follow upnya juga nggak jalan karena penyuluh mau datang kalau pada saat jam kerja, sedangkan Bu Eny juga bekerja. Bu Eny beranggapan uang 100 ribu yang di berikan kepada muallaf lebih baik di alokasikan ke pendidikan para anak muallaf.

Selanjutnya Bu Sri terkait pembinaan muallaf di Kementerian Agama Kota Malang. Selaras dengan Bu Eny dari penjelasan Bu Sri di atas pembinaan yang selama ini di lakukan sebanyak tiga kali, empat kali dengan buka puasa bersama. Isinya penguatan keyakinan bagi muallaf, penguatan ekonomi dengan di tawari pinjaman modal oleh baznas. setelah itu di kasih uang 100 ribu, Bu Sri juga mengatakan bahwa Kementerian Agama mempersilahkan muallaf menghubungi penyuluh setempat sebagai upaya follow up materi bagi muallaf, namu Bu Sri malu karena Bu Sri bisanya hanya jam malam, sedangkan jam malam bukan jam kerja. Namun $\mathrm{Bu}$ Sri mengamini pembinaan yang selama ini dilakukan namun Bu Sri ingin dibina agar $\mathrm{Bu}$ Sri punya usaha dirumah.

Kemudian pendapat Bu Sofia terkait pembinaan keluarga muallaf. Berbeda dari penjelasan infroman sebelumnya Bu Sofia lebih beranggapan bahwa pembinaan yang selama ini dilakukan Kementerian Agama tidak efektif, karena nggak ada follow upnya. Pembinaan hanya bersifat efentual, akhirnya Bu Sofia mencari sendiri kebenaran agama yang di anutnya saat ini dengan ustad di desanya. Bu Sofia juga berpendapat bahwa muallaf harus di kasih prosedurnya secara jelas terkait peminjaman modal yang akan di kasihkan ke muallaf. Supaya muallaf tidak bingun terkait hal itu.

Selanjutnya pendapat Bu Lusy terkait pembinaan muallaf yang selama ini di lakukan oleh Kementerian Agama: Tidak jauh beda dengan informan sebelumya Bu Lusy menilai pembinaan yang selama ini di lakukan sudah cukup baik, karena pengetahuan yang Bu Lusy tidak dapatkan di luar bisa di dapat di saat pembinaan, namun Bu Lusy menyarankan supaya pembinaan di lakukan pada saat hari libur supaya yang datang banyak. Kemudian pembinaan juga isinya jangan ceramah saja karena bikin ngantuk, Bu Lusy menyarankan agar ada praktek sholat atau ngaji karena kebetulan Bu Lusy belum bisa sholat dan mengaji.

Pendapat Bu Agip tentang pembinaan yang selama ini dilakukan oleh Kementerian Agama Kota Malang: Tidak jauh berbeda dengan informan sebelumnya Bagi Ibu Agip pembinaan yang sampai saat ini dilakukan sudah bagus, namun kurang efektif, karena isinya cuman ceramah. Dari awal pembinaan sampai saat ini isinya hanya ceramah, penyuluh juga yang di tugaskan setiap kecamatan juga belum terfungsikan dengan baik, mungkin karena muallaf bisa dibinanya pada hari libur, sedangkan hari libur bukan jam kerja. Maka dari itu penyuluh tidak bisa datang kerumah. 
Model pembinaan yang dilakukan di Kementerian Agama Kota Malang adalah model ceramah dengan penggunaan audio visual, paket dakwah, personal approach/konsultasi. Kemudian dari segi ekonomi modelnya adalah memberikan pinjaman modal (berkelompok) kepada setiap keluarga muallaf, dan juga pengembangan skill sebagai upaya untuk mensejahterakan muallaf. Masing masing model memiliki fungsi dan metode yang berbeda, oleh karena itu masing masing model pembinaan harus memiliki kesinambungan agar pembinaan tepat sasaran dan maksimal. Yang pertama terkait model ceramah dengan menggunakan audio visual di Kementerian Agama dengan pemateri K.H.Baidlowi Muslih, beliau adalah sosok yang alim dan memiliki keluasan ilmu. Model seperti ini evektif untuk mentransfer ilmu pengetahuan tentang Islam. namun jika durasi waktu ceramah terlalu lama maka akan menjadi jenuh, Hal ini seperti yang di ungkapkan beberapa muallaf. Kemudian terkait paket dakwah, model ini juga sudah dilakukan Kementerian Agama dengan memberikan alquran buku panduan Islam dan uang seniali seratus ribu. Seperti yang diungkapkan oleh Pak Basuki. Kemudian terkait model personal approach atau konsultasi. Model seperti ini sebenarnya sangat efektif karena bisa dilakukan perindividu. Namun seperti yang di uangkapkan bu mahmudah bahwa mereka bisa ke rumah muallaf asal saat jam kerja sedangkan muallaf saat jam kerja juga sibuk bekerja. kemudian Bu Agip juga mengatakan bahwa penyuluh sudah di hubungi namun tidak mau datang gara gara hari minggu, jika di biarkan seperti ini maka pembinaan secara personal tidak akan maksimal, padahal pembinaan secara personal adalah sebagai ujung tombak sebagai upaya follow up dari materi materi yang telah disampaikan, karena dapat mengetahui langsung permasalahan keluarga muallaf seperti yang dikatakan Pak Basuki. Maka dari itu penyuluh memang harus memiliki kesadaran lebih bahwa mereka adalah pembina masyarakat, jadi kapanpun masyarakat membutuhkanya agar bisa membantu. Selain itu memiliki empati, dalam hal mengidentifikasi diri dengan orang lain dari berbagai perspektif dan perasaan seakan mengalaminya sendiri juga perlu dimiliki oleh pembina, serta kemampuan mengalokasikan waktu, khususnya pada persoalan yang rumit dan kerelaan untuk terus membina masyarakat. Agar pembinaan yang dilakukan di Kementerian Agama tidak bersifat efentual.

Hal ini memang sulit, namun bisa dilakukan. apalagi dengan banyaknya penyuluh, seperti yang dikatakan Pak Basuki bahwa penyuluh berjumlah 7 yang PNS dan yang tidak PNS berjumlah 41, ini adalah jumlah yang sangat banyak. Jadi jika secara aturan atau sistematis sudah baik, tinggal pelaksanaanya agar berjalan maksimal. Sesuai dengan firman Allah dalam yang berbunyi:

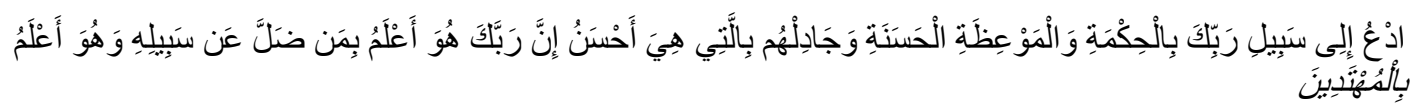

"Serulah (manusia) kepada jalan Tuhan-mu dengan hikmah dan pelajaran yang baik dan bantahlah mereka dengan cara yang baik. Sesungguhnya Tuhanmu Dialah 
yang lebih mengetahui tentang siapa yang tersesat dari jalan-Nya dan Dialah yang lebih mengetahui orang-orang yang mendapat petunjuk.(Al-Qur'an 16:125)"

Dari ayat di atas sudah jelas bahwa Allah menyuruh hambanya yang mengetahui untuk menyeru kebaikan dan kebenaran kepada yang butuh di beri penjelasan tentang kebenaran. Oleh karena itu tanggung jawab untuk membina keluarga muallaf adalah kewajiban seluruh umat muslim di sekitar orang yang membutuhkan kebenaran, namun terkhusus tetap pada Kementerian Agama Kota Malang.

Kemudian terkait pembinaan dari segi ekonomi, para muallaf ada yang berpendapat bahwa muallaf kesulitan untuk mengajukan pinjaman modal usaha karena modelnya kelompok, sedangkan setiap muallaf inginya individu. Padahal ini bukan menjadi masalah, karena model kelompok hanya saat pengajuanya saja, jika sudah cair maka pengalokasianya bebas. Model kelompok seperti ini bertujuan agar baznas mudah dalam mengkoordinir penagihan uang, karena setiap kelompok tersebut di bentuk koordinator. Namun muallaf yang akan mengajukan modal pinjaman maka akan disurvei terlebih dahulu. Tidak langssung diterima. Ini sebenarnya bukan menjadi masalah, hanya saja butuh pemahaman lebih dari para muallaf. Agar lebih jujur, karena seperti kata gus sulton bahwa saat ini dibentuk model seperti ini karena dulu pernah ada yang masalah dan tidak ada pertanggung jawaban. Kemudian gus sulton juga mengatakan bahwa jika ada mualaf yang belum punya ide bisnis atau skill berusaha maka akan di bimbing oleh baznas, karena baznas sekarang juga punya ukm ukm yang sudah berkembang. Pernyataan seperti ini sebenarnya adalah peluang besar bagi para muallaf yang berada pada usia produktif untuk mengembangkan skill dan ekonomi keluarga. Apalagi dizaman sekarang yang serba canggih dengan kemajuan teknologi banyak sekali lapangan pekerjaan baru seperti gojek dan bisnis online.

Firman Allah (و المولفة قلوبهم) Walmuallafa quluubuhum / yang di jinakkan hati mereka. Garis besarnya dapat dibagi dua. Pertama orang kafir, dan kedua Muslim. Yang pertama terbagi dua, yaitu yang memiliki kecenderungan memeluk Islam, maka mereka dibantu, dan yang kedua mereka yang dikhawatirkan gangguannya terhadap Islam dan umatnya. Adapun yang Muslim, terdiri dari sekian macam. Pertama, mereka yang belum mantap imannya dan diharapkan bila diberi akan menjadi lebih mantap. Kedua mereka yang mempunyai kedudukan dan pengaruh dalam masyarakat dan diharapkan dengan memberinya akan berdampak positif terhadap yang lain. Ketiga, mereka yang diberi dengan harapan berjihad melawan para pendurhaka atau melawan para pembangkang zakat (Muhammad, 2009).

Dari penjelasan di atas dapat disimpulan bahwa Muallaf itu orang yang baru memeluk Islam dan dirangkul serta diteguhkan hati mereka dalam keIslaman. Karena mereka baru memeluk Islam dan baru mengetahui agama Islam maka, mereka berada pada posisi pihak yang 
membutuhkan pembinaan dan bimbingan agama Islam. Agar mereka dapat mengetahui syariat Islam untuk kemudian dapat mengamalkan syariat itu dalam sehari-hari.

Pada masa Nabi SAW para Muallaf tersebut diposisikan sebagai penerima zakat untuk menjamin kelestarian mereka kepada Islam dengan terus memberikan pembinaan dan pengajaran tentang agama Islam. Salah satu alasan Nabi SAW memberikan zakat kepada mereka adalah menyatukan hati mereka pada Islam. Oleh karena itu mereka dinamakan al-Muallafah Qulubuhum (Masyah, 2002).

Dari pernyataan tersebut, pada zaman dahulu muallaf sudah diberi bantuan agar iman mereka kuat, kemudian bisa jihad menyebarkan agama Islam. Tidak jauh beda dengan hari ini, dengan tantangan zaman yang semakin berat maka setiap muallaf atau keluarga muallaf membutuhkan skill untuk merekea berkreasi.

Model pembinaan yang efektif dilakukan adalah pemantapan atau follow up. Konsepnya didatangi perumah, Karena dapat bertemu langsung otomatis muallaf punya, karena selama ini yang dilakukan adalah model ceramah, berdasarkan paparan para informan, banyak informan yang mengantuk dan tidak fokus.

\section{KESIMPULAN}

Keluarga muallaf di bawah binaan Kementerian Agama Kota Malang berdasarkan data pembinaan berjumlah 29 orang, mayoritas dari mereka sudah berkeluarga. latar belakang mereka memeluk agama islam mayoritas karena mengikuti agama suami, namun ada juga yang lewat gelojolak hati dan hidayah. dari segi agama secara aqidah sudah yakin betul dengan agama yang dipilihnya, kemudian secara pelaksanaan syariat dasar seperti sholat dan membaca Al-Quran sudah bisa menjalankan dengan baik, hanya saja masih butuh pembinaan lanjutan, kemudian dari segi keluarga sakinah mereka sudah saling mengerti walaupun dengan kondisi pengetahuan agama yang seadanya. Hal ini dibuktikan dengan jarangnya terjadi cekcok dalam keluarga, hanya masalah kecil dalam rumah tangga seperti salah faham, namun hal seperti ini bukan menjadi masalah bagi mereka. Namun terkait ekonomi para keluarga muallaf memang sangat minim dan butuh sekali pengembangan skill. Agar ekonomi dari setiap keluarga muallaf meningkat. Sehingga tidak memberikan celah sedikitpun kepada agama lain untuk membujuk kembali ke agama selain Islam. ataupun paham radikalisme yang selama ini menjalar disetiap elemen masyarakat.

Pembinaan keluarga muallaf yang selama ini dilakukan di Kementerian Agama Kota Malang sudah berjalan, namun belum maksimal. Selama ini beberapa model pembinaan yang sudah dijalankan seperti paket dakwah, model ceramah dan penggunaan audio visual. Namun hal itu belum di dukung dengan follow up yang maksimal dari setiap penyuluh, padahal ujung tombak atau senjata utama dari pembinaan keluarga muallaf adalah lewat penyuluh, agar 
tersampaikan apa saja terkait indicator keluarga sekinah seperti ekonomi, agama, sosial dan pendidikan. Kendala yang selama ini terjadi yaitu terkait jam kerja penyuluh yang terbatas, kemudian muallaf yang sibuk dan hanya bisa pada saat weekend atau luar jam kerja, oleh Karena itu butuh alokasi waktu yang efisien dan empati lebih sebagai seorang pembina agar berjalan maksimal.

\section{DAFTAR PUSTAKA}

Al-Qur'an.

Amiruddin, \& Asikin, Z. (2004). Pengantar metode penelitian hukum. Jakarta: PT. RajaGrafindo Persada. Retrieved from http://www.worldcat.org/title/pengantar-metode-penelitianhukum/oclc/969582940\&referer=brief_results.

Bogdan, R., \& Biklen, S. K. (1992). Qualitative research for education: An introduction to theory and methods. USA: Allyn and Bacon.

LKP2M. (2005). Research book for LKP2M. Malang: UIN Malang.

Masyah, S. H. (2002). Hikmah di balik hukum Islam. Jakarta: Mustaqim.

Muhammad, A. J. (2009). Tafsir Ath-thabari. Jakarta: Islam Rahmatan.

Prawira, A. R. (2001). Petunjuk praktis bagi calon pemeluk agama Islam. Jakarta: YPI Al-Azhar.

Singarimbun, M., \& Effendi, S. (1987). Metode penelitian survei. Jakarta: LP3ES. 